\title{
Effects of drought on the physicochemical, nutrient and carbon metrics of flows in the Savannah River, Georgia, USA.
}

\author{
Kelsey A. Wilbanks ${ }^{1}$, Lori A. Sutter ${ }^{2}$, and Darold P. Batzer ${ }^{1}$ \\ ${ }^{1}$ University of Georgia Department of Entomology \\ ${ }^{2}$ University of Georgia Warnell School of Forestry and Natural Resources
}

February 11, 2022

\begin{abstract}
Hydrological drought has wide-ranging impacts on water quality, nutrient and carbon metrics that are critical to investigate with the increased drought frequency predicted with climate change. This study compared physicochemical parameters (temperature, conductivity, $\mathrm{pH}$ and $\mathrm{DO}$ ), nutrients ( $\mathrm{TN}, \mathrm{NO}_{\mathrm{x}}, \mathrm{NH}_{3}, \mathrm{TP}$ ) and carbon (TOC and DOC) between hydrological drought conditions (2006-2009) and hydrological normal conditions (2016-2019) at five sites along the lower Savannah River (Georgia, USA). We unexpectedly found temperature $\left(\mathrm{F}_{1,220}=4.27, \mathrm{p}=0.04\right)$ was significantly lower during drought conditions. Levels of $\mathrm{pH}\left(\mathrm{F}_{1,220}=11.99, \mathrm{p}<0.01\right)$ and $\mathrm{DO}\left(\%\right.$ saturation; $\mathrm{F}_{1,220}=9.17, \mathrm{p}=0.01$; and $\left.\mathrm{mg} \mathrm{L}^{-1} ; \mathrm{F}_{1,220}=4.04, \mathrm{p}<0.01\right)$ were significantly higher during drought. We found $\left.\mathrm{TN}_{(1,220}=5.23, \mathrm{p}=0.02\right)$, TOC $\left(\mathrm{F}_{1,220}=30.22, \mathrm{p}<0.01\right)$ and DOC concentrations $(\mathrm{F}$ $1,220=30.22, \mathrm{p}<0.01)$ were significantly lower during drought, but $\mathrm{NO}_{\mathrm{x}}$ concentrations $\left(\mathrm{F}_{1,219}=4.04, \mathrm{p}=0.05\right)$ were significantly higher during drought. Conductivity only varied at the lower river sites, being significantly higher during drought at Sites 3 (F $1,47=12.56, \mathrm{p}<0.01), 4\left(\mathrm{~F}_{1,47}=12.96, \mathrm{p}<0.01\right)$ and $5\left(\mathrm{~F}_{1,34}=17.60, \mathrm{p}<0.01\right)$. These complex changes could be attributed to volume reductions coupled with an increase in the percentage of total flow originating from groundwater and limnetic reservoir inputs, persistent point source pollution, reduced natural catchment inputs and/or reduced floodplain interactions. The changes that occurred during drought may be disruptive to aquatic life, not only from reduced water quantity but also due to a scarcity of some biologically essential materials and lower food resources, combined with artificially high levels of some other potentially stressful materials.
\end{abstract}

\section{Hosted file}

Wilbanks et al. 020622.docx available at https://authorea.com/users/459894/articles/556008effects-of-drought-on-the-physicochemical-nutrient-and-carbon-metrics-of-flows-in-thesavannah-river-georgia-usa 